\title{
IMPLEMENTASI KEBIJAKAN PENGELOLAAN SAMPAH DI KABUPATEN KUDUS
}

\author{
Abdul Wachid ${ }^{1,}$ David Laksamana Caesar ${ }^{2}$ \\ ${ }^{1,2}$ Program Studi S1 Kesehatan Masyarakat STIKES Cendekia Utama Kudus \\ E-mail: abdulw4ch1d78@gmail.com
POLICY IMPLEMENTATION OF WASTE MANAGEMENT IN KUDUS REGENCY

\begin{abstract}
Indonesia is estimated to produce as much as 64 million tons of waste every year. This figure is very high because only 7 percent of the total destruction has been managed. Kudus Regency has a policy on waste management, but most people in Kudus Regency do not yet know the policy. This study aims to determine the implementation of waste management policies in Kudus Regency. This type of research is qualitative research, with four informants. The research instrument used an interview guide, a recording device, and a camera. The analysis method uses a thematic content analysis. Based on the results of the research, it is known that the local government has not carried out mass socialization of waste management policies to the community so that many people from various groups do not know this regulation. The implementation of waste management in the Kudus Regency is also constrained by a limited budget and waste processing equipment. In also besides, monitoring and evaluation activities are also only a formality because there is no follow-up to the monitoring and evaluation activities every year.
\end{abstract}

\begin{abstract}
Abstrak
Indonesia diperkirakan menghasilkan sampah sebanyak 64 juta ton setiap tahun. Angka ini sangat tinggi, karena baru 7 persen saja dari jumlah sampah tersebut yang telah dikelola. Kabupaten Kudus telah mempuyai kebijakan tentang pengelolaan sampah, namun kebijakan tersebut belum diketahui oleh sebagian besar masyarakat di Kabupaten Kudus. Penelitian ini bertujuan untuk mengetahui implementasi kebijakan pengelolaan sampah di Kabupaten Kudus. Jenis penelitian ini adalah penelitian kualitatif, dengan jumlah informan 4 orang. Instrument penelitian menggunakan panduan wawancara, alat perekam, dan kamera. Metode analisis menggunakan thematic content analysis. Berdasarkan hasil penelitian diketahui pemerintah setempat belum melakukan kegiatan sosialisasi kebijakan pengelolaan sampah kepada masyarakat secara massif, sehingga banyak masyarakat dari berbagai kalangan yang belum mengetahui peraturan ini. pelaksanaan pengelolaan sampah di Kabupaten Kudus juga terkendala dengan keterbatasan anggaran dan peralatan pengolah sampah. Selain itu, kegiatan monitoring dan evaluasi juga hanya sebagai formalitas saja, karena tidak ada tindak lanjut dari kegaitan monitoring dan evaluasi tersebut setiap tahun.
\end{abstract}




\section{PENDAHULUAN}

Indonesia

diperkirakan

menghasilkan 64 juta ton sampah setiap tahunnya. Namun, merujuk data Sustainable Waste Indonesia (SWI) tahun 2017, dari angka tersebut baru 7 persen yang didaur ulang, sementara 69 persen di antaranya menumpuk di tempat pembuangan akhir (TPA). Lebih parahnya lagi 24 persen sisanya dibuang sembarangan dan mencemari lingkungan sehingga dikategorikan sebagai illegal dumping. ${ }^{1}$

Sampah adalah sisa kegiatan seharihari manusia dan atau proses alam yang berbentuk padat. $^{2}$ Saat ini sampah dan limbah telah menjadi permasalahan nasional. Menurut hasil surevei dari Badan Pusat Statistik (2018) masalah persampahan sangat terkait dengan pertambahan penduduk, pertumbuhan ekonomi dan perubahan pola konsumsi masyarakat. Pada tahun 2017 jumlah penduduk Indonesia sudah mencapai 261,89 juta jiwa meningkat dibanding tahun 2000 yang sebesar 206,26 juta jiwa. Kondisi tersebut menimbulkan bertambahnya volume, beragamnya jenis, dan karakteristik sampah dan limbah. Menurut KLHK dan Kementrian Perindustrian tahun 2016, jumlah timbulan sampah di Indonesia sudah mencapai 65,2 juta ton pertahun ${ }^{3}$

Kementerian Lingkungan Hidup dan Kehutanan telah mencanangkan program Indonesia Bebas Sampah tahun 2020. Salah satu konsekuensinya dari dicanangkanya program itu adalah adanya gerakan pengelolaan sampah secara masal dan sistematis. Salah satu upaya yang dilakukan adalah mengeluarkan kebijakan dengan menerbitkan undang-undang tentang persampahan dan aturan-aturan lain yang ada dibawahnya.

Pemerintah telah mengatur tentang mekanisme pengelolaan sampah, definisi sampah, dan hak kewajiban pihak-pihak yang terlibat dalam pengelolaan sampah dalam Undang-Undang nomor 18 tahun 2008 dan aturan turunya yang tertuang dalam Peraturan Pemerintah nomor 81 tahun 2012. Dua dasar hukum inilah yang kemudian menjadi pedoman bagi terbitnya peraturan-peraturan lain yang ada di tingkat daerah. Salah satu peraturan daerah yang muncul sebagai bentuk implementasi pelaksanaan amanat undang-undang nomor 18 tahun 2008 adalah Peraturan Daerah nomor 4 tahun 2017 tentang Pengelolaan Sampah yang dikeluarkan oleh Pemerintah Kabupaten Kudus. ${ }^{4}$ 
Kabupaten Kudus sebagai salah satu kota industry di provinsi Jawa Tengah sangat berpotensi menghasilkan timbulan sampah dalam jumlah besar. Tidak hanya dari sector domestic seperti rumah tangga, dan fasilitas umum lainnya, namun juga dari sector industry juga menyumbang banyaknya timbulan sampah di Kabupaten Kudus.

Berdasarkan data dari Dinas Perumahan, Kawasan Pemukiman, dan Lingkungan Hidup Kabupaten Kudus diketahui pada tahun 2017 rata-rata timbulan sampah yang dihasilkan di Kabupaten Kudus adalah 636,3 $\mathrm{m}^{3} /$ hari, sedangkan jumlah yang terangkut ke TPA hanya 501,2 $\mathrm{m}^{3} /$ hari. Artinya masih ada kurang lebih 21\% sampah di Kabupaten Kudus yang belum dikelola dengan baik oleh Pemerintah Daerah. ${ }^{5}$

Berdasarkan hasil studi pendahuluan yang dilakukan peneliti juga diketahui kondisi Tempat Pembuangan Akhir (TPA) Tanjungrejo Kabupaten Kudus dalam kondisi darurat. Karena timbulan sampah sudah hampir melebihi batas maksimum daya tampung TPA. Selain itu, berdasarkan pengamatan peneliti, jumlah timbulan sampah di TPA Tanjungrejo saat ini sudah sangat meningkat pesat dibandingkan pada tahun 2016 ketika peneliti pertama kali melakukan observasi ke TPA tersebut. Peraturan daerah yang sudah dibuat oleh pemerintah Kabupaten Kudus harusnya dapat menjadi salah satu solusi untuk mengatasi permasalah sampah ini. Namun ternyata peraturan ini belum cukup kuat untuk memberikan edukasi kepada masyarakat tentang pentingnya pengelolaan sampah dan bahayanya sampah ketika tidak dikelola dengan baik.

Berdasarkan penelitian yang dilakukan oleh David dan Ervi tahun 2019 diketahui bahwa sebagian masyarakat Kabupaten Kudus belum mengetahui adanya peraturan daerah ini, padahal kemauan masyarakat untuk mengelola sampah sangat tinggi. ${ }^{6}$ Oleh karena itu, penelitian mengenai implementasi pelaksanaan Peraturan Pemerintah Kabupaten Kudus tentang Pengelolaan Sampah perlu dilakukan.

\section{BAHAN DAN METODE}

Jenis dan rancangan penelitian yang digunakan pada penelitian ini adalah studi kualitatif. Dimulai dari pengumpulan data sampai pengambilan kesimpulan secara umum. Penelitian kualitatif dipilih karena lebih sensitif dan adaptif terhadap peran dan berbagai pengaruh yang timbul. Disamping itu, karena peneliti akan mencoba menggali 
atau mengeskplorasi, pengetahuan bagaimana kenyataan yang ada di lapangan. ${ }^{7}$

Penelitian ini dilaksanakan di beberapa instansi di Kabupaten Kudus antara lain Dinas Perumahan, Kawasan Pemukiman, dan Lingkungan Hidup (PKPLH), Kantor DPRD Kabupaten Kudus, dan TPA Tanjungrejo Kabupaten Kudus. Penelitian mulai dilaksanakan di bulan Mei sampai dengan Agustus 2020.

Pengambilan sumber data penelitian ini menggunakan tehnik Purposive Sampling, yaitu pengambilan sampel didasarkan pada pilihan penelitian tentang aspek apa dan siapa yang dijadikan fokus pada situasi tertentu dan saat ini terus menerus sepanjang penelitian. ${ }^{7}$ Subjek penelitian terdiri dari 4 orang terdiri dari masing-masing perwakilan instansi yang menjadi tempat penelitian.
Proses pengumpulan data dalam penelitian ini menggunakan instrument pedoman wawancara, tape recorder, dan kamera. Sedangkan proses pengolahan data diawali dengan mentranskripsikan seluruh data secara utuh berdasarkan topik, dikembangkan ke bentuk bahasa yang lebih baku, secara naratif dan direduksi dalam rangkuman. Kemudian data dianalisis menggunakan metode Tematic Content Analysis (TCA) yaitu menganalisis dan menyimpulkan isi dari tema yang dipilih. Selanjutnya dilakukan pengelompokan untuk mencari keterkaitan antar berbagai variabel tersebut. ${ }^{8}$

\section{HASIL}

Penelitian tentang implementasi kebijakan pengelolaan sampah di Kabupaten Kudus ini dilakukan pada 4 orang informan, dengan karakteristik sebagai berikut:

Tabel 1. Karakteristik Informan Penelitian

\begin{tabular}{cccl}
\hline No & Informan & Pendidikan & \multicolumn{1}{c}{ Jabatan } \\
\hline 1 & Informan 1 & S1 & Ka. Seksi Dinas PKPLH Kab. \\
& & S2 & Kudus \\
2 & Informan 2 & S1 UPT TPA Tanjungrejo Kudus \\
3 & Informan 3 & S1 & DPRD Kab. Kudus \\
4 & Informan 4 & Aktifis Lingkungan Kab. Kudus \\
\hline
\end{tabular}

Penelitian ini mencoba meliputi 1) Pelaksanaan sosialisasis mengungkap beberapa variable penelitian peraturan daerah tentang pengelolaan 
sampah di Kabupaten Kudus, 2)

Pelaksanan peraturan daerah dan 3)

Monitoring dan evaluasi pelaksanaan

peraturan daerah tentang pengelolaan

sampah.

\section{Sosialisasi Peraturan Daerah}

Berdasarkan hasil penelitian

diketahui, secara umum latar belakang
2017 tentang Pengelolaan Sampah adalah adanya aturan serupa di tingkat pusat, yaitu Undang-Undang No. 18 Tahun 2008, kemudian disusul terbitnya Peraturan Pemerintah No. 81 Tahun 2012 tentang Pengelolaan Sampah Rumah Tangga dan Sampah Sejenis Sampah Rumah Tangga. Berikut kutipan hasil wawanca dengan para informan penelitian.

lahirnya Peraturan Daerah Nomor 4 Tahun

Kotak 1

“.... selama ini belum pernah ada kegiatan sosialisasi Perda ini, karena memang tidak ada anggaranya. Dan biasanya Dinas hanya menunggu permintaan dari warga untuk melakukan sosialisasi.....” (Informan 1)

“.... sepengatuhuan Saya memang selama ini belum pernah ada sosialisasi pak tentang Perda tersebut .....” (Informan 2)

“..... Kalo DPR memang tidak ada tupoksi sosialisasi mas, tapi tergantung kemauan konstituen juga sebenarnya. Tapi setau Saya, sejauh ini masalah sampah belum menjadi prioritas dewan.....” (Informan 3)

“.... Setau saya memang Perda sampah ini belum pernah disosialisasikan ke masyarakat Kudus mas. Di tempat Saya sendiri pemerintah desa belum tahu tentang peraturan tersebut .....” (Informan 4)

\section{Pelaksanaan Peraturan Daerah}

Inti dari Peraturan Daerah No. 4 Tahun 2017 ini adalah adanya upaya dari segenap masyarakat Kabupaten Kudus untuk dapat mengelola sampahnya dengan baik. Pemerintah sebagai garda terdepan dalam menggerakan masyarakat untuk mengelola sampah secara mandiri sekaligus sebagai penyedia sarana pengelolaan sampah untuk masyarakat Kabupaten Kudus. Berikut hasil kutipan wawancaranya bersama informan.

\footnotetext{
Kotak 2

“..... Pemerintah Kabupaten Kudus telah menyediakan beberapa TPS baik menggunakan bangunan permanen ataupun Bak Truk. Selai itu disediakan juga truk untuk mengangkut sampah yang ada di TPS setiap hari...." (Informan 1)

“.... TPA Tanjungrejo masih menjadi tempat utama dalam pengelolaan sampah di Kabupaten Kudus. Belum semua industry mempunyai tempat pengelolaan sampah mandiri, jadi volume sampah disini sangat besar....." (Informan 2)

“.... Sebenarnya jauh sebelum adanya peraturan ini, sudah ada retribusi yang dikenakan bagi siapa saja yang akan membuang sampah di TPA Tanjungrejo.....” (Informan 3)

“.... Pelaksanaan pengelolaan sampah di Kabupaten Kudus menurut Saya masih belum optimal. Apalagi kondisi TPA yang sekarang sudah sangat tidak layak dan hampir penuh volumenya.....” (Informan 4)
} 


\section{Monitoring dan Evaluasi Pengelolaan}

\section{Sampah di Kabupaten Kudus}

Kegiatan pengelolaan sampah di Kabupaten Kudus telah dilaksanakan di bawah kendali Dinas Perumahan, Kawasan Pemukiman, dan Lingkungan Hidup
(PKPLH) melalui UPT TPA Tanjungrejo. Berdasarkan hasil penelitian diperoleh informasi terkait evaluasi pengelolaan sampah selama ini dari para informan sebagai berikut.

\section{Kotak 3}

“..... Menurut Saya pemerintah kabupaten harus menambah alokasi anggaran untuk kegiatan pengelolaan sampah di Kudus pak. Selain itu, peremajaan truk-truk sampah juga sangat dibutuhkan untuk meningkatkan pelayanan masyarakat....." (Informan 1)

".... Kalo saya evaluasinya mungkin segera saja merealisasikan lahan baru untuk tempat pengelolaan sampah. Kalo tidak memungkinkan nggih segera saja diadakan peralatan pengolah sampah, sehingga volume sampah disini bisa berkurang.....” (Informan 2)

".... Sekarang legislative itu posisinya tidak seperti zaman dulu pak. Jadi memang kuasa penuh anggaran sekarang ada di Eksekutif. Dan sampai saat ini usulan masyarakat tentang sampah memang belum ada ke kami...." (Informan 3)

“.... Hendaknya mulai dari tahap sosialisasi dilakukan dengan baik oleh pemerintah, sehingga masyarakat bisa mengetahui adanya peraturan ini. Selain itu, jadikan sampah sebagai prioritas program kerja pemerintah Kabupaten Kudus. Karena sampah bisa jadi bom waktu. Kapan waktunya pasti akan jadi permasalahan bagi sebuah daerah...." (Informan 4)

\section{PEMBAHASAN}

\section{Sosialisasi Peraturan Daerah}

Berdasarkan Hasil penelitian tersebut menunjukan bahwa kegiatan sosialisasi Peraturan Daerah No. 4 Tahun 2017 belum dilaksanakan oleh Pemerintah Kabupaten Kudus. Padahal, kegiatan sosialasasi menjadi salah satu kunci sukses sebuah peraturan daerah dapat dipatuhi oleh masyarakat. Apabila kegiatan sosialisasi dilaksanakan secara optimal, maka secara perlahan-lahan masyarakat akan dapat merubah sikapnya menjadi lebih peduli terhadap pengelolaan lingkungan.
Pemberian informasi melalui kegiatan sosialisasi merupakan bentuk upaya pemberian edukasi kepada masyarakat, sehingga pengetahuan dan pemahaman masyarakat mengenai peraturan daerah tersebut meningkat. Peningkatan pengetahuan yang terus menerus dapat berdampak kepada perububahan sikap dan praktik masyarakat. Hal ini sesuai dengan penelitian yang dilakukan oleh David dan Ervi tahun 2018. Berdasarkan hasil penelitian ini diketahui rata-rata pengetahuan dan sikap masyarakat Desa Cranggang tentang sanitasi lingkungan sudah cukup baik 
ditunjukan dengan rata-rata nilai skor pengetahuan 77 dan rata-rata skor sikap 68.7 Berdasarkan hasil penelitian tersebut, menunjukan tingginya pemahaman masyarakat Desa Cranggang mengenai sanitasi lingkungan, namun tidak berbanding lurus dengan perilaku untuk menjaga kesehatan lingkungan, karena faktanya masih ditemukan masyarakat yang membuang sampah dan limbah di sungai, serta memanfaatkan air sungai sebagai sarana MCK. Perilaku yang secara terus menerus dilakukan akan menjadi sebuah kebiasaan dan budaya bagi masyarakat yang sulit untuk dirubah. ${ }^{9}$

\section{Pelaksanaan Peraturan Daerah}

Pelaksanaan pengelolaan sampah di Kabupaten Kudus terpusat di TPA Tanjungrejo yang berada di Desa Tanjungrejo Kecamatan Dawe Kabupaten Kudus. Di TPA ini menerima sampah yang berasal dari sejumlah TP yang ada di Kabupaten Kudus. Penganggkutan menggunakan truk-truk sampah ataupun secara mandiri dilakukan oleh masyarakat ke TPA Tanjungrejo. Rata-rata jumlah sampah yang terangkut setiap hari adalah 150 ton/hari.

Sebelum sampah di angkut kedalam truk-truk sampah, petugas akan melakukan pemilahan terlebih dahulu di setiap TPS. Walaupun prosesnya belum berjalan secara optimal, namun proses pemilahan ini sudah sesuai dengan standar operasional prosedur yang ada. Pemilahan ini juga bisa mengurangi volume sampah yang masuk ke dalam TPA Tanjungrejo. Setelah sampai di TPA, para pemulung juga akan kembali melakukan pemilahan sampah, sehingga sampah yang benar-benar akan dimasukan dalam tahapan pengolahan akhir adalah sampah yang telah terseleksi di TPS dan di TPA oleh para pemulung.

Teknik pengolahan sampah yang dilakukan oleh pengelola TPA Tanjungrejo sampai saat ini adalah Controlled Landfill, karena keterbatasan anggaran dan sarana sehingga tidak memungkinkan untuk dilakukan pengolahan akhir menggunakan teknik Sanitary Landfill. Perbedaan yang cukup jelas dari kedua jenis pengolahan ini adalah pada masa waktu pengurugan sampah. Pada sanitary landfill pengurugan dilakukan setiap hari, sedangkan pada controlled landfill dilakukan 2 sampai 7 hari sekali. Metode sanitary landfill sebenarnya merupakan metode terbaik dalam pengelolaan sampah, karena pengurugan dilakukan selapis demi selapir, sehingga emisi sampah tidak menjadi sumber pencemar bagi lingkungan. Secara 
umum pengelolaan sampah di Kabupaten

bawah ini:

Kudus dapat digambarkan dalam bagan di

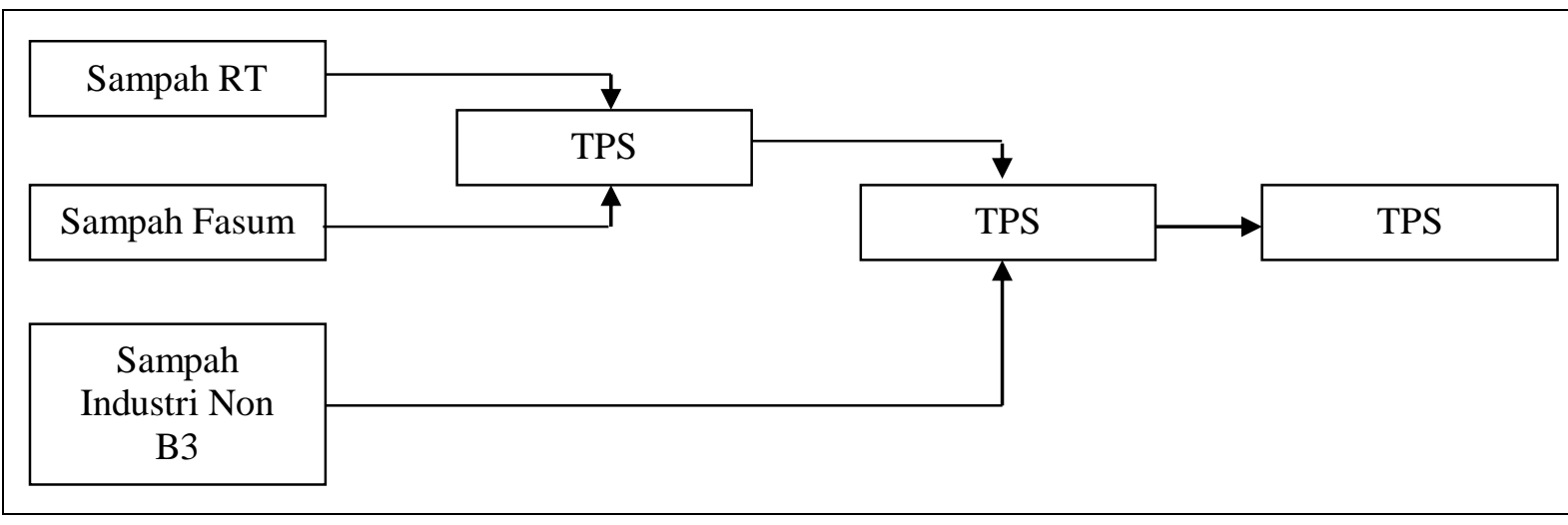

Selain permasalahan teknis dalam

perkembangan organisasi pada pengelolaan sampah, pelaksanaan pemerintahan dibentuk bada yang peraturan ini juga belum sepenuhnya berjalan karena banyak pelanggar peraturan ini yang tidak mendapatkan sanksi tegas dari pemerintah ataupun aparat terkait. Banyak kasus terjadi dilapngan orang atau sekelompok masyarakat yang secara sengaja membuang tidak pada tempatnya hanya diberikan denda yang nilainya sangat rendah, sehingga tidak memberikan efek jera bagi masyarakat.

Pelaksanaan pengelolaan sampah memang memiliki perbedaan di setiap daerah. Seperti penelitian yang dilakukan oleh Surahma, Adi, dan Noeng di Provinsi Yogyakarta pada tahun 2014. Pada awalnya pengelolaan sampah di DIY dikelola oleh DPU. Namun sejalan dengan dikhususkan untuk mengelola lingkungan khususnya sampah di DIY. ${ }^{10}$

Sedangkan dalam penelitian Agung Prasetya di Kabupaten Tuban pada tahun 2016 diketahui pengelolaan sampah di Kabupaten Tuban ditangani oleh Bidang Kebersihan dan Pertamanan pada Dinas Pekerjaan Umum Kabupaten Tuban, menggunakan metode end of pipe solution, yaitu berupa kegiatan pengumpulan, pengangkutan, dan pembuangan sampah ke TPA. ${ }^{11}$

Sama halnya dengan di Kabupaten Tuban, di Kota Manado pengelolaan sampah berada di bawah kendali Dinas Lingkungan Hidup Kota Manado. Pelaksanaan pengelolaan sampah di Manado menyelenggarakan kegiatanya 
berdasarkan Peraturan Daerah Kota Manado nomor 7 Tahun 2006 tentang Pengelolaan Persampahan di Kota Manado. ${ }^{12}$

$$
\text { Pengelolaan sampah di Kota }
$$
Malang mengacu kepada Peraturan Daerah Nomor 1 Tahun 2011 tentang Pengelolaan Sampah di Kabupaten Malang. Dinas Cipta Karya dan Tata Ruang Kabupaten Malam membagi 7 wilayah pelayanan dimana setiap wilayah dilayani oleh satu unit pelaksana teknis dinas (UPTD). Untuk sarana dan prasarana yang tersedia antara lain 11 drum truk, 18 arm rolls, 99 kontainer, 103 barrows, 6 wagon motor. Dan jumlah tenaga kebersihan sebanyak 171 pasukan. ${ }^{13}$

\section{Monitoring dan Evaluasi Pengelolaan} Sampah

Beberapa aspek tentang pelaksanaan peraturan daerah telah dijalankan oleh pemerintah daerah dan pemangku kepentingan lain. Namun, masih terdapat beberapa evaluasi yang harus diperbaiki oleh Pemerintah Daerah Kabupaten Kudus guna meningkatkan upaya pengelolaan sampah antara lain 1) Mensosialisasikan peraturan daerah secara masih kepada masyarakat lewat berbagai macam media, 2) Menambah sarana pengangkutan sampah, 3) Menyediakan lahan baru yang lebih representative untuk pengelolaan sampah, 4) Menyediakan sarana pengolahan sampah akhir yang efektif, dan 5) Memberikan sanksi tegas bagi pelanggar peraturan ini.

Menurut Asti, Adi, dan Noeng dalam penelitian yang dilakukan di Yogyakarta diketahui pemerintah DIY mengalokasikan anggaran cukup besar untuk kegiatan pengelolaan sampah disana. Pada tahun 2012 saja, anggaran yang digelontrokan untuk mengelola sampah sebesar Rp. 12 miliar lebih untuk proses pengelolaan sampah. Hal ini berbanding terbalik dengan alokasi anggaran yang ada di Kabupaten Kudus. ${ }^{14}$

Penelitian Surahma dkk juga menunjukan bahwa belum ada dokumen laporan pemantauan dan evaluasi kebijakan pengelolaan sampah di DIY. Namun, telah ada data-data yang secara periodic diperbaharui untuk mengetahui kondisi persampahan di wilayah masingmasing yang berada di bawaha naungan DIY. ${ }^{10}$

Upaya pemda mewujudkan penerapan kebijakan pengelolaan sampah secara terpadu dimulai dari dukungan berbagai perangkat hukum dan peraturan pemeritah, peraturan perundang-undangan, 
dan peraturan lain. Kebijakan pengelolaan sampah dapat memberikan kepastian hokum dalam perencaan dan pemanfaatan bagi pemerintah, pengusaha, pemulung, bank sampah, LSM, dan masyarakat. ${ }^{15}$

\section{KESIMPULAN}

Peraturan Daerah Nomor 4 Tahun 2017 tentang Pengelolaan Sampah di Kabupaten Kudus merupakan implementasi dari Undang-Undang Nomor 18 Tahun 2008 tentang Persampahan. Peraturan ini telah cukup lama ada, namun belum banyak masyarakat yang mengetahui tentang keberadaan peraturan daerah ini. Keterbatasan anggaran menjadi factor utama yang menjadikan kegiatan sosialisasi peraturan daerah ini belum bisa disosialisasikan kepada masyarakat Kabupaten Kudus. Adanya peraturan ini belum menjadikan aspek pengelolaan sampah di Kabupaten Kudus menjadi perhatian bagi pemerintah daerah. Karena faktanya masih ditemukan problematika tentang pengelolaan sampah di Kabupaten Kudus mulai dari lahan yang habis, jumlah truk sampah yang kurang, tenaga operasional pengelola sampah yang tidak mencukupi, dan alat untuk pengolahan sampah yang belum tersedia.

\section{UCAPAN TERIMA KASIH}

Ucapan terima kasih disampaikan kepada DRPM Kementerian Ristekbrin atas Hibah Proposal Dosen Pemula dengan Surat Perjanjian Kontrak PDP Nomor 055/LL6/PG/SP2H/AMD/PL.II/2020.

\section{DAFTAR RUJUKAN}

1. Badan Pusat Statistik. 2018. Statistik Lingkungan Hidup Indonesia 2018 Hutan dan Perubahan Iklim. Badan Pusat Statistik. Jakarta.

2. Menteri Hukum dan HAM RI. 2008. Undang-Undang No. 18 Tahun 2008 tentang Persampahan. Kementerian Hukum dan HAM. Jakarta.

3. Subdirektorat Statistik Lingkungan Hidup. 2018. Statistik Lingkungan Hidup Indonesia 2018. Badan Pusat Statistik: Jakarta.

4. Sekertariat Daerah Kabupaten Kudus. 2017. Peraturan Daerah Kabupaten Kudus Nomor 4 Tahun 2017 tentang Pengelolaan Sampah. Pemerintah Daerah Kudus: Kudus.

5. Pemda Kudus, 2017 http://kuduskab.go.id/p/154/persampaha n diakses tanggal 19 Agustus 2019

6. Caesar DL. PENGEMBANGAN KEBIJAKAN BEHAVIOR SANITATION CULTURE PADA MASYARAKAT DESA CRANGGANG KUDUS. J-KESMAS: Jurnal Kesehatan Masyarakat. 2019 Nov 30;5(2):71-82.

7. Sugiono. Memahami Penelitian Kualitatif. Alfabeta: Bandung. 2009

8. Moleong. 2009. Metodologi Penelitian Kualitatif. Remaja Rosdakarya: Bandung.

9. Caesar DL, Dewi ER. Pengaruh Media Buku Saku Terhadap Pengetahuan Tentang Sanitasi Lingkungan Pada 
Kader Kesehatan Desa Cranggang. JKM (Jurnal Kesehatan Masyarakat) Cendekia Utama. 2018 Aug 28;6(1):137-46.

10. Mulasari SA, Husodo AH, Muhadjir N. Kebijakan pemerintah dalam pengelolaan sampah domestik. Kesmas: National Public Health Journal. 2014 May 1;8(8):404-10.

11. Mayangkara AP. Evaluasi Kebijakan Pengelolaan Sampah di TPA Gunung Panggung Kabupaten Tuban. JPAP: Jurnal Penelitian Administrasi Publik. 2016 Oct 17;2(02).

12. Mokodompis Y, Kaunang M, Kasenda V. Implementasi Kebijakan Pengelolaan Sampah Di Kota Manado. JURNAL EKSEKUTIF. 2019 Jul 10;3(3).
13. Arief S. Pengelolaan sampah malang raya menuju pengelolaan sampah terpadu yang berbasis partisipasi masyarakat. Jurnal Humanity. 2015 Sep 25;9(1).

14. Mulasari SA, Husodo AH, Muhadjir N. Analisis situasi permasalahan sampah kota Yogyakarta dan kebijakan penanggulangannya. KEMAS: Jurnal Kesehatan Masyarakat. 2016 Jan 24;11(2):259-69.

15. Suyanto E, Soetarto E, Sumardjo S, Hardjomidjojo HS. Model Kebijakan Pengelolaan Sampah Berbasis Partisipasi "Green Community" Mendukung Kota Hijau. MIMBAR: Jurnal Sosial dan Pembangunan. 2015 Jun 8;31(1):143-52. 